УДК 378.046.4+821+159.923.2

DOI: https://doi.org/10.54662/veresen.2.2021.09

\author{
Володимир Гладищев, \\ ORCID iD 0000-0001-7232-4184 \\ доктор педагогічних наук, професор, \\ професор кафедри теорії й методики \\ мовно-літературної та художньо-естетичної \\ освіти \\ Миколаӥвський обласний \\ інститут післядипломної педагогічної освіти \\ вул. Адміральська, 4-а, 54001, м. Миколаїв, Україна \\ volodymyr.hladyshev@moippo.mk.ua
}

\title{
МОДЕЛЮВАННЯ ТРАЕКТОРІЇ ПРОФЕСІЙНОГО РОЗВИТКУ: ЗДІЙСНЕННЯ ПСИХОЛОГІЧНОЇ САМОДОПОМОГИ ЗАСОБАМИ БІБЛІОТЕРАПЕВТИЧНОГО ЧИТАННЯ
}

Стаття репрезентує один із найважливіших напрямів моделювання вчителем траєкторії професійного розвитку, процесу, який на сучасному етапі життя краӥни в цілому та освіти зокрема потрібно визнати доленосним як щодо окремої людини, так i України в цілому, оскільки саме професійно підготовлені кадри вирішують сьогодення та майбутнє нашого суспільства. Аналізується специфіка траєкторії професійного розвитку та напрямів ї̈ реалізачії, виявляється роль самоосвіти та саморозвитку в иъвому проиесі, визначається психологічна стійкість як важливий чинник ефективного професійного розвитку. Подається характеристика бібліотерапевтичного читання як ефективного засобу здійснення вчителем психологічної самодопомоги.

Ключові слова: бібліотерапевтичне читання; бібліотерапія; психологічна самодопомога; самоосвіта; саморозвиток; траєкторія професійного розвитку.

(C) Гладишев В. В., 2021

Вступ. Потрібно зазначити, що останнім часом суспільство має можливість спостерігати системну, наполегливу та скоординовану діяльність законодавчої й виконавчої гілок української влади з реформування освіти. Свідченням цього вважаємо не лише прийняття нових законів про освіту (Закон України «Про освіту», 2020), а й системні зміни до вже чинних законів (Закон України «Про вищу освіту», 2020; Закон України «Про повну загальну середню освіту», 2020), прийняття Постанови Кабінету Міністрів України (Постанова Кабінету Міністрів України «Деякі питання професійного розвитку педагогічних працівників», 2021), що переводять реалізацію Концепції «Нова українська школа» (Нова українська школа, 2016) у практичну площину.
На нашу думку, серед дев'ятьох ключових компонентів, на основі яких складається/будується Концепція Нової української школи, одним із найважливіших треба вважати «сучасне освітнє середовище, яке забезпечить необхідні умови, засоби і технології для навчання учнів, освітян, батьків не лише в приміщенні навчальних закладів» (Нова українська школа, 2016). Цей компонент працює на перспективу, забезпечує розвиток українського суспільства на принципово нових засадах щодо осмислення ролі освіти в житті людини та країни.

За таких умов на сучасному етапі розвитку української школи зазначене вище освітнє середовище має перетворювати звичайний - начебто - процес навчання на 
перший, найважливіший, крок залучення школярів до своєрідного, можна назвати його так, «освітнього стилю життя» людини. Ідеться про неперервний «освітній ланцюжок»: для сучасного українця освіта має починатись як для учня, триватиме після школи, коли людина здобуває професію; освіта набуває нового змісту в житті, коли людина приводить до школи свою дитину - i, зрештою, не закінчується ніколи! Вочевидь, у сучасному світі постійна освіта та особистісно-професійне самовдосконалення є обов'язковими умовами досягнення життєвого успіху, побудови гідного життя для себе та своєї родини, запорукою свідомого ставлення до країни та своїх громадянських обов'язків.

Окреме питання сучасної, тобто вже нової української школи, - це обов'язковість постійного навчання вчителя, людини та професіонала, ключової постаті у процесі формування особистості школяра, його особистісного зростання. Якісне виконання своїх професійних обов'язків стає можливим лише за умов постійного професійного самовдосконалення, яке починається у процесі здобуття фахової освіти у відповідному закладі освіти, та триває все професійне життя вчителя.

Створена раніше система післядипломної освіти вчителів забезпечувала професійне зростання вчителя, але вона була ефективною лише в рамках тодішніх вимог до вчителя та його професіоналізму. Утім, нові виклики часу вимагають принципових змін у забезпеченні професійного самовдосконалення вчителя, створення нового підходу до цього важливого для фахівця та школи в цілому процесу.

Зважаючи на потреби часу, коли відповідальність за професійне зростання вчителя стає не лише проблемою держави, а значною мірою зміщується в особистісну площину, керівники освіти нашої країни визначили, що провідним напрямом професійного самовдосконалення вчителя має стати моделювання ним його особистої «траєкторії професійного розвитку». Що це таке?
У згаданій вище Постанові КМУ визначається, що «траєкторія професійного розвитку педагогічного працівника - персональний шлях реалізації професійного потенціалу педагогічного працівника, що грунтується на його вільному виборі закладу освіти, установи, організації, іншого суб'єкта освітньої діяльності, видів, форм, темпу здобуття освіти та освітньої програми в рамках здобуття освіти дорослих» (Постанова Кабінету Міністрів України «Деякі питання професійного розвитку педагогічних працівників», 2021). Як бачимо, увагу акцентовано саме на особистості педагогічного працівника, на його власному виборі, на визначенні ним шляху власної освіти - та, звичайно, на його власній відповідальності за свій вибір, за його наслідки та результати для власної особистості та професійного життя.

Оскільки раніше формували так звану «колективну відповідальність» за професійне зростання вчителя, коли кожні декілька років учитель приходив на курси перепідготовки, перехід на персональну відповідальність не може бути миттєвим та безболісним. Потрібно передбачити основні труднощі цього перехідного періоду та допомогти вчителеві їх подолати.

У рамках реалізації Концепції «Нова українська школа», як справедливо зазначає В. І. Шуляр, провідна роль належить саме вчителеві (Шуляр В. І., 2019; Шуляр В. І., 2020), відповідно, безпосередньо від результативності його дій, спроможності ефективно планувати та моделювати процес професійного самовдосконалення, від уміння брати відповідальність на себе та досягати результату залежить створення належного освітнього середовища як у школі, так і в суспільстві.

Цілі статті. Цілями статті є:

1. Визначити специфіку напрямів моделювання траєкторії професійного розвитку.

2. Визначити роль психологічного стану вчителя, психологічної стійкості у його професійній діяльності та особистому житті, що суттєво впливає на виконання профе- 
сійних обов'язків; з'ясувати вплив психологічної стійкості на спроможність свідомо ставитися до професійного самовдосконалення.

3. Визначити провідні «особистісні запити» вчителя («професійні» та «особисті»), показати можливість відшукати відповіді на них через бібліотерапевтичне читання.

4. 3'ясувати можливості бібліотерапевтичного читання як чинника формування психологічної стійкості вчителя.

5. Визначити етапи бібліотерапевтичного читання та специфіку кожного з них.

Специфіка напрямів моделювання траєкторії професійного розвитку вчителя. Моделювання траєкторії професійного розвитку вчителя - процес складний, проте в ньому потрібно виділити відповідні напрями, кожен із яких відбиває важливу складову траєкторії професійного розвитку.

Г. П. Полякова зауважує, що «Індивідуальну траєкторію освіти педагогічного працівника можна розглядати як доцільний вибір ним змісту, форм, методів, технологій, прийомів освіти на основі узгодження індивідуальних цілей, потреб, мотивів, інтересів працівника та цілей, вимог освітньої організації (навчального закладу, установи)» (Полякова Г. П., 2010). Як бачимо, авторка підкреслює важливість гармонійного поєднання двох чинників: індивідуальності педагогічного працівника та специфіки закладу освіти, у якому він працює.

Моделювання вчителем індивідуальної траєкторії освіти обов'язково має здійснюватися за двома напрямами: «по-перше, за вибором організованих форм системи неперервної освіти (підготовка, перепідготовка, підвищення кваліфікації); по-друге, шляхом моделювання змісту й засобів самоосвіти та саморозвитку» (Полякова Г. П., 2010). На нашу думку, на сучасному етапі розвитку української школи в рамках кожного 3 цих напрямів мають відбутися кардинальні зміни, але якщо за систему неперервної освіти педагогічних працівників, за «організовані форми» реалізації траєкторії професійного розвитку «відповідає» дер- жава, то за самоосвіту та саморозвиток відповідальність несе саме вчитель. I ось тут багато залежить від психологічного стану вчителя, його психологічної стійкості, готовності сприймати нове, навчатися новому, стимулювати себе, від уміння уникати «психологічних провалів», відновлювати психологічну рівновагу.

Якщо підсумувати, то можна стверджувати: саме психологічний стан учителя, його психологічна стійкість «відповідають» за свідоме ставлення до власного життя як на особистісному, так і на професійному рівнях, за самоосвіту та саморозвиток.

Психологічний стан учителя. Від психологічного стану людини залежить ii життя - ідеться про майже всі аспекти життєдіяльності. Якщо подивитися на професію вчителя під кутом зору «витрат енергії) (мається на увазі не лише психологічна сфера особистості, а й звичайні «фізичні сили»), то потрібно визнати, що 3-поміж інших вона є однією 3 найбільш «енерговитратних».

Учитель постійно працює 3 людьми, його професійна діяльність відбувається за умов, коли ані на хвилину не можна дозволити собі «розслабитися», тому що до нього постійно прикуті погляді дітей, колег, батьків... Цей психологічний тиск є одним із об'єктивних чинників професії вчителя, проте звикнути до нього неможливо, не помічати його неможливо - його постійно відчуваєш. Отже, потрібно дбати про мінімізацію негативних наслідків психологічного тиску на вчителя, щоб він міг бути людиною, яка «під тиском» адекватно сприймає життя й себе в житті; щоб відчував психологічну рівновагу, спроможність зосередити увагу на виконанні професійних обов'язків, для чого потрібно почуватися вільно та поводитися невимушено.

Упоратися з психологічним тиском на себе вчителеві досить складно навіть тоді, коли він уже має великий досвід роботи, що ж тоді казати про вчителів-початківців, які лише нещодавно відчули психологічний тягар професії? За таких умов досить важ- 
ко мотивувати себе на професійне самовдосконалення, тим більше - свідомо моделювати траєкторію професійного розвитку в напрямі самоосвіти та саморозвитку. Психологічний тиск, по-перше, не стимулює бажання розвиватися, по-друге, заважає правильно обрати шляхи саморозвитку й самоосвіти, оскільки вчитель більш-менш, але спотворено сприймає себе, учнів, школу, батьків учнів, колег.

Психологічний тиск на вчителя одна 3 причин того, що молоді вчителі, що прагнули належним чином оволодіти професією, утрачають інтерес до неї та залишають школу. У житті вчителя дуже багато «зон ризику», які ставлять питання та формують те, що у психотерапії має назву «запиту», відповіді на які вчитель не може отримати в рамках «організованих» форм реалізації траєкторії професійного розвитку, оскільки вони мають особистісну природу.

Провідні «особистісні запити» вчителя. Серед «особистісних запитів», які 3'являються в учителя внаслідок значних «енерговитрат» під час виконання ним його професійних обов'язків, можливо виділити дві групи: професійні та індивідуальні. Цей розподіл має дещо умовний характер, тому що в житті вчителя нічого не можна розділити на професійне та особисте, індивідуальне, тому ці «складові», як зазначалося вище, взаємопов'язані. Але у будь-якому «особистісному запити» переважає або професійне, або індивідуальне.

Докладна характеристика «особистісних запитів» 3 обох груп подана нами у відповідній книзі (Гладишев В. В., 2020, с. 29-79). Нагадаємо лише, що вони собою являють.

Можна виділити такі «професійні особистісні запити»:

1. Чи є я «людиною на своєму місці», або Я і моя професія?

2. Я та мої колеги.

3. Я та батьки учнів.

4. Я та учні (Гладишев В. В., 2020, c. 29-50).

«Індивідуальні особистісні запити» вчителя - це питання:

1. Я та моє здоров'я.

2. Я та мої «зони відповідальності».

3. Я та самотність.

4. Я та моя родина (партнер та діти).

5. Я та мій фінансовий стан (Гладишев В. В., 2020, с. 50-79).

Якщо подивитися на «особистісні запити» обох груп, то не можна не визнати, що вирішення цих проблем має велике значення для особистості, оскільки воно забезпечує психологічну стійкість, робить учителя впевненішим у власних силах, що не може позитивно не впливати на його професійну діяльність та особисте життя. Водночас треба поставити питання: «А чи може вчитель, не докладаючи зусиль, вирішити ці проблеми?» Звичайно, ні.

Проте лише зусиль недостатньо. Специфіка «особистісних запитів» полягає в тому, що частіше за все людині досить важко розібратись у собі, зрозуміти, що відбувається, відповідно, правильно сформулювати цей запит. Але ж саме від правильного формулювання запиту багато в чому залежить результативність вирішення проблеми, з якою він пов'язаний.

У психологічній практиці з'ясуванням «природи запиту» займаються психолог або психотерапевт. Звичайно, було б дуже добре, якби кожен учитель мав можливість співпрацювати із психотерапевтом або психологом, проте, на жаль, у нашому суспільстві до цього ще далеко. Тому вчителеві потрібно ставати «самому собі психотерапевтом», здійснювати психологічну самодопомогу, нейтралізувати негативні психологічні чинники, інакше йому забезпечене «професійне вигорання»: «Професійне вигорання - це виснаження емоційних, розумових і енергетичних ресурсів людини, яке розвивається на тлі сильного хронічного стресу в роботі. Виявляється повною втратою інтересу до професійної діяльності і відчуттям безглуздості подальшого розвитку, браком сил і бажання займатися діяльністю, яка нещодавно була по-справжньому цікавою» (Професійне вигорання, 2020). Із метою уникнення «професійного виго- 
рання» доцільно використовувати доволі простий для вчителя (зважаючи на його інтелектуальну підготовку та сформовані професією вміння працювати 3 літературою), але дуже ефективний метод бібліотерапевтичного читання.

Бібліотерапевтичне читання. Бібліотерапевтичне читання - це вид читання, який здійснюється в рамках бібліотерапії: «Книголікування, або бібліотерапія» (3 грецьк. «книголікування») - психологічна допомога, зняття душевного стресу і лікування людей, в основі якого лежить читання ними книжок певного змісту і тематики. Як окремий вид терапії з'явився на початку $\mathrm{XX}$ ст., хоч цілком очевидним $\epsilon$ те, що книголікування як явище застосовувалося вже в середньовіччі, у всякому разі з тих часів залишилися згадки окремих людей (переважно монахів), які описують зцілювальну силу, яку дає читання святих книг (Святого Письма, творів святих отців) і навпаки руйнівну силу недобрих книжок і текстів, які несуть стрес і можуть нервово виснажувати людину (чорнокнижжя)» (Бібліотерапія).

Бібліотерапія як наука перебуває на межі медицини та бібліотечної справи. Використання психотерапевтом художньої та спеціальної літератури пов'язане із запитами пацієнта-клієнта, для чого фахівець підбирає спеціальну літературу, читання та кваліфіковане обговорення якої допомагає не лише з'ясувати природу особистісних запитів, а й забезпечує позитивний вплив на особистість пацієнта-клієнта.

На сучасному етапі розвитку суспільства до бібліотерапії прикута увага багатьох спеціалістів різного профілю. Вивчення бібліотерапії передбачене під час підготовки бібліотечних працівників, розгляду іiі як ефективного чинника їxньої професійної підготовки присвячені фундаментальні праці д.пед.н. Ю. М. Дрешер (Дрешер Ю. М., 2007; Дрешер Ю. М., 2008). Різноманітні зв'язки між бібліопсихологією та бібліотерапією досліджуються у праці під загальною редакцією психологів Н. С. Лейтеса, Н. Л. Карпової, О. Л. Кабачек (Лейтес Н. С., 2005). Польська до- слідниця I. Борецька (Борецка И., 2006) розглядає актуальні питання теорії та практики бібліотерапії, пропонує ефективні варіанти іiі застосування в діяльності бібліотечних працівників. Науково-популярний розгляд засад бібліотерапії подано у праці психолога О. О. Мішукової (Мишукова Е. О., 2011). Цікавим потрібно вважати огляд творів світової літератури під кутом зору використання цих творів як матеріалу для бібліотерапевтичного впливу на особистість, авторами якого є британські бібліотерапевти Е. Берту та С. Елдеркін (Берту Э., Элдеркин С., 2016).

Нагадаємо, що 3 метою здійснення психологічної самодопомоги ми пропонуємо вчителеві не власне бібліотерапію, яка є зовнішнім впливом на особистість, а бібліотерапевтичне читання, що являє собою своєрідну «автобібліотерапію» (Гладишев В. В., 2020, с. 10). Його перевага полягає в тому, що вчитель може оперативно, без вичікування зустрічі з терапевтом, реагувати на зміни свого психологічного стану, здійснювати психологічну самодопомогу, спираючись на свої особистісно-читацькі інтереси, ураховуючи свій читацький та особистісний досвід.

Якщо вчитель звикає до застосування бібліотерапевтичного читання, систематично його використовує, він набуває психологічної стійкості, що умовно можна назвати «ефектом неваляйки» (Гладишев В. В., 2020 , с. 18-21). Це робить учителя більш мотивованим та забезпечує, по-перше, якісніше виконання ним професійних обов'язків, по-друге, більш свідоме ставлення до самоосвіти та саморозвитку, що дозволяє якісно моделювати траєкторію професійного розвитку та цілеспрямовано реалізовувати цей розвиток як у рамках «організованих» форм реалізації траєкторії, так і в рамках самоосвіти та саморозвитку.

Щоби бібліотерапевтичне читання було результативним, учителеві потрібно оволодіти його методикою.

Етапи бібліотерапевтичного читання. Бібліотерапевтичне читання відрізняється від звичайного тим, що має цілеспря- 
мований характер, тобто твори, до яких звертається читач, пов'язані 3 його особистісними запитами. Для вчителя це має надзвичайно важливе значення, тому що правильне визначення запиту та правильний підбір твору забезпечують позитивний вплив на психологічний стан та відновлення психологічної рівноваги.

Цілісність та ефективність процесу бібліотерапевтичного читання зумовлені тим, що він складається з низки взаємопов'язаних етапів (Гладишев В. В., 2020, c. 23-28), на кожному з яких читач активно діє та аналізує власну діяльність.

Основні етапи бібліотерапевтичного читання:

1. Визначення запиту. На цьому етапі читач робить спробу визначити витоки психологічного дискомфорту, сформулювати «особистісний запит» та зорієнтуватися (спираючися на досвід), звернення до якого твору/творів могло б допомогти у вирішенні проблеми.

2. Вибір твору, до якого доцільно звернутися. Великого значення набуває попередній досвід, наявність у читача власного «золотого списку» творів, звернення до яких раніше допомагало вирішити проблему. Цей список складається лише «для себе», тому там можуть буди будь-які твори, головне - щоб вони відповідали душевному настрою, були «співзвучні» переживанням читача. Тому цей список творів має поширюватися, до нього мають додаватися твори, які «довели» свою ефективність.

3. Власне читання твору. Потрібно створити найсприятливішу атмосферу для повного занурення читача в текст. Позитивний уплив читання здійснюється за рахунок повноцінного емоційного «перебування» у світі, що створений письменником у творі. Тобто, звертаючись до твору, читач здобуває досвід емоційних переживань, яких у його реальному житті не могло бути. Це формує психологічні механізми захисту від негативного впливу життєвих обставин, підвищує психологічну стійкість на рівні власного емоційного досвіду. Також на цьому етапі починається аналітичне зіставлення запиту та емоційного впливу твору на читача.

4. Зіставлення запиту та впливу читання твору, виявлення, наскільки запит був точним, а читання ефективним. На цьому етапі може виявитися, що запит був сформульованим не зовсім точно, але це не означає, що читання було безрезультатним.

Знову підкреслимо, що процес бібліотерапевтичного читання $\epsilon$ цілісним, етапи його взаємопов'язаними, вони перетинаються між собою, їхня взаємодія у свідомості читача має індивідуальний характер. Проте системне використання бібліотерапевтичного читання дисциплінує читача, робить це читання більш результативним.

Висновки. Розгляд проблеми здійснення вчителем психологічної самодопомоги засобами бібліотерапевтичного читання в рамках моделювання траєкторії професійного розвитку надав можливість зробити такі основні висновки:

- напрям моделювання траєкторії професійного розвитку, у рамках якого моделюються самоосвіта та саморозвиток, $\epsilon$ дуже важливим для вчителя, від нього багато в чому залежить реалізація моделі;

- психологічний стан учителя, його психологічна стійкість багато в чому визначають мотивацію моделювання траєкторії самоосвіти та саморозвитку, тому вони мають бути на оптимальному для адекватного моделювання рівні;

- «особистісні запити» вчителя, які стають причинами психологічного дискомфорту, тяжіють до професійних та індивідуальних, але вони $є$ взаємопов'язаними, учителеві важко відшукати відповіді на ці запити самому, тому потрібно або звертатися до психологів/психотерапевтів, або використовувати засоби, які полегшують психологічну самодопомогу, серед яких провідне (відповідно до специфіки професійної діяльності вчителя) місце може посісти бібліотерапевтичне читання;

- бібліотерапевтичне читання передбачає цілеспрямоване звернення до твору, воно забезпечує можливість здобуття емоційного досвіду, алгоритмів поведінки в 
життєвих ситуаціях за рахунок занурення читача у створений письменником світ, що робить читача стійкішим психологічно та озброює його моделями поведінки в різних життєвих ситуаціях;

- системне використання бібліотерапевтичного читання значно підвищує емоційну стійкість учителя, формує вміння швидко «психологічно відновлюватися» після емоційних «провалів», що робить учителя більш урівноваженою людиною та забезпечує свідоміше та адекватне моделювання траєкторії професійного розвитку в напрямі самоосвіти та саморозвитку.

\section{Перспективи подальшого дослі-} дження:

- виявлення зв'язку між моделюванням траєкторії професійного розвитку (напрям - самоосвіта та саморозвиток) та бібліотерапевтичним читанням із урахуванням фаху вчителя;

- підсилення особистісного компонента бібліотерапевтичного читання, застосування його вчителем для вирішення особистісних проблем та особистісного розвитку.

\section{ЛІТЕРАТУРА}

1. Берту Э. Книга как лекарство : скорая литературная помощь от А до Я / Э. Берту, С. Элдеркин . - Москва : Синдбад. - 2016. - 490 с.

2. Библиопсихология и библиотерапия ; [под. ред. Н. С. Лейтес, Н. Л. Карпова, О. Л. Кабачек]. - Москва : Шк. б-ка. - 2005. - 479 с.

3. Бібліотерапія. - Режим доступу на 20.01.2021 - https://uk.wikipedia.org/wiki/\%D0 $\% 9 \mathrm{~A} \% \mathrm{D} 0 \% \mathrm{BD} \% \mathrm{D} 0 \% \mathrm{~B} 8 \% \mathrm{D} 0 \% \mathrm{~B} 3 \% \mathrm{D} 0 \% \mathrm{BE} \% \mathrm{D} 0 \% \mathrm{BB} \% \mathrm{D} 1 \% 96 \% \mathrm{D} 0 \% \mathrm{BA} \% \mathrm{D} 1 \% 83 \% \mathrm{D} 0 \%$ B2\%D0\%B0\%D0\%BD\%D0\%BD\%D1\%8F Бібліотерапія

4. Борецка И. Библиотерапия. Лекции / И. Борецка. - Лекции. - Гродно : ГрГУ, 2007. - 100 с. Пер. с польского И. Ф. Притульчик.

5. Гладышев В. В. Библиотерапевтическое чтение - инструмент психологической самопомощи учителя : справочные материалы / В. В. Гладышев, С. А. Гладышева. - Николаев : НОИППО, 2020. - 96 с.

6. Дрешер Ю. Н. Библиотерапия. Полный курс : учеб. пособие / Ю. Н. Дрешер. - М. : «Издательство ФАИР». - 2007. - 560 с.

7. Дрешер Ю. Н. Библиотерапия : теория и практика : учебное пособие / Ю. Н. Дрешер. - СПб. : «Профессия». - 2008. - 269 с.

8. Закон України «Про вищу освіту» - [Електронний ресурс]. - Режим доступу: https://zakon.rada.gov.ua/laws/show/1556-18\#Text

9. Закон України «Про освіту» - [Електронний ресурс]. - Режим доступу станом на 20.01.2021 - https://zakon.rada.gov.ua/laws/show/2145-19\#Text

10. Закон України «Про повну загальну середню освіту» - [Електронний ресурс]. Режим доступу на 20.01.2021 - https://zakon.rada.gov.ua/laws/show/463-20\#Text

11. Мишукова Е. О. Лечение книгой, или Основы библиотерапии / Е. О. Мишукова. - Москва : ЦБС № 3 ЮАО, Библиотека-филиал № 172 «Просвещение трудящихся», 2011. $-19 \mathrm{c}$.

12. Нова українська школа - [Електронний ресурс]. - Режим доступу на 20.01.2021 - $\quad$ https://mon.gov.ua/storage/app/media/zagalna\%20serednya/nova-ukrainska-shkolacompressed.pdf

13. Полякова Г. П. Напрями моделювання індивідуальної траєкторії безперервної освіти й самоосвіти педагогічних працівників / Г. П. Полякова // Теорія та методика управління освітою. - 2010. - № 3. - 11 с. - [Електронний ресурс]. - Режим доступу на 20.01.2021 - http://umo.edu.ua/images/content/nashi_vydanya/metod_upr_osvit/v_3/28.pdf

14. Постанова Кабінету Міністрів України «Деякі питання професійного розвитку педагогічних працівників» від 29 липня 2020 р. № 672 - [Електронний ресурс]. - Режим доступу на 20.01.2021 - https://ips.ligazakon.net/document/view/kp200672?an=1\&ed=2020_07_29

15. Професійне вигорання. - Режим доступу на 20.01.2021 - https://happymonday.ua/ 
shho-take-profesijne-vygorannya

16. Шуляр В. І., Гладишев В. В. Педагогічна школа видатного методиста Ніли Йосипівни Волошиної / В. І. Шуляр, В. В. Гладишев // Pedagogy inmodernconditions: collective monograph / Bartienieva I., Nozdrova O., - etc. - International Science Group. - Boston : Primediae Launch, 2020. 329 p. DOI: 10.46299/ISG.2020.MONO.PED.III. URL: https://isgkonf.com. - C. 95-99.

17. Шуляр В. І. Стратегії організації освітнього процесу : до реалізації Концепції «Нова українська школа» / В. І. Шуляр // Директор школи. - 2019. - № 7 (847). - С. 93-104.

18. Шуляр В. І. Учитель як людський ресурс Нової української школи : навчальний посібник / В. І. Шуляр. - Миколаїв : МОІППО, 2020. - 50 с.

\title{
МОДЕЛИРОВАНИЕ ТРАЕКТОРИИ ПРОФЕССИОНАЛЬНОГО РАЗВИТИЯ: ОСУЩЕСТВЛЕНИЕ ПСИХОЛОГИЧЕСКОЙ САМОПОМОЩИ СПОСОБАМИ БИБЛИОТЕРАПЕВТИЧЕСКОГО ЧТЕНИЯ
}

\author{
Гладышев Владимир, \\ доктор педагогических наук, профессор, \\ професор кафедры теории и методики \\ языково-литературного и художественно-эстетического образования \\ Николаевский областной институт \\ последипломного педагогического образования \\ ул. Адмиральская, 4-а, 54001, г. Николаев, Украина \\ volodymyr.hladyshev@moippo.mk.ua
}

Статья представляет одно из наиболее важных направлений моделирования учителем траектории профессионального развития, процесса, который на современном этапе жизни страны в целом и образования в частности необходимо признать судьбоносным как относительно отдельного человека, так и Украины в целом, потому что именно профессионально подготовленные кадры будут определять как настоящеее, так и будущее нашего общества. Анализируется специфика траектории профессионального развития и направлений её реализации, выясняется роль самообразования и саморазвития в этом прочессе, определяется психологическая устойчивость в качестве важного фактора эффективного профессионального развития. Представлена характеристика библиотерапевтического чтения как эффективного способа осуществления учителем психологической самопомощи.

Ключевые слова: библиотерапевтическое чтение; библиотерапия; психологическая самопомощь; самообразование; саморазвитие, траектория профессионального развития.

\section{MODELING THE PROFESSIONAL DEVELOPMENT: PSYCHOLOGICAL SELF-HELP BY METHODS OF BIBLIOTHERAPEUTIC READING}

\author{
Hladyshev Volodymyr, \\ Doctor of Pedagogical Sciences, Professor \\ Department of Theory and Methods of Language, \\ Literature, Art and Aesthetic Education \\ Mykolaiv In-Service Teachers Training Institute \\ 4-a Admiralska Street, Mykolaiv, 54001, Ukraine \\ volodymyr.hladyshev@moippo.mk.ua
}

The article presents the important direction of the teacher's professional development. Such a process nowadays may be recognized as fateful in relation to both the individual and 
Ukraine as a whole. Since professionally trained staff determines the prospects for social development and in the future it will even more influence. The specifics and the directions of teacher professional development are analyzed. It is emphasized that the advanced teacher's training provided by the state must necessarily be combined with personal activity, including self-education and self-development. To ensure high-quality self-education, the teacher needs to be balanced psychologically, to be able to cope with stress and negative factors. Psychological stability is very important for a teacher, it ensures harmony both in the profession and in personal life. Psychological self-help can be an effective tool, which is carried out by the teacher within the biblio-therapeutic reading. It can be a perfect option for restoring psychological balance especially taking into account the high level of the teacher's reading activity). The most promising areas of research on this topic within the framework of the teacher's professional development have been determined.

Keywords: bibliotherapeutic reading; bibliotherapy; psychological self-help; selfdevelopment; self-education; teacher's professional development.

\section{REFERENCES}

1. Bertu, Je. \& Jelderkin, S. (2016) Kniga kak lekarstvo: skoraja literaturnaja pomoshh ot A do $\mathrm{Ja}$ [A bookasmedicine: emergency literary aid from A to Z] (rus).

2. Biblioterapiia [Bibliotherapy]. Retrieved from: https://uk.wikipedia.org/wiki/\%D0\%9 A $\%$ D0\%BD $\%$ D0\%B8\%D0\%B3\%D0\%BE\%D0\%BB\%D1\%96\%D0\%BA\%D1\%83\%D0\%B2 $\% \mathrm{D} 0 \% \mathrm{~B} 0 \% \mathrm{D} 0 \% \mathrm{BD} \% \mathrm{D} 0 \% \mathrm{BD} \% \mathrm{D} 1 \% 8 \mathrm{~F}$ (ukr).

3. Borecka, I. (2007). Biblioterapija. Lekcii [Bibliotherapy. Lections]. (I. F. Pritulchik, Trans.).Grodno: GrGU (rus).

4. Dresher, Ju. N. (2007). Biblioterapija. Polnyj kurs [Bibliotherapy. Completebook]. Moskva: FAIR (rus).

5. Dresher, Ju. N. (2008). Biblioterapija: teorija i praktika [Bibliotherapy: theory and practice]. Sankt-Peterburg: Professija (rus).

6. Hladyshev, V. V. \& Hladysheva, S. A. (2020). Biblioterapevticheskoe chtenie instrument psihologicheskoj samopomoshhi uchitelja [Bibliotherapeutic reading - a tool for psychological self-help of teachers]. Nikolaev: NOIPPO (rus).

7. Law of Ukraine «On complet e general secondary education». Retrieved from: https:// zakon.rada.gov.ua/laws/show/463-20\#Text (ukr).

8. Law of Ukraine «On Education». Retrieved from: https://zakon.rada.gov.ua/laws/ show/2145-19\#Text (ukr).

9. Law of Ukraine «On Higher Education». Retrieved from: https://zakon.rada.gov.ua/ laws/show/1556-18\#Text (ukr).

10. Lejtes, N. S., Karpova, N. L. \&amp; Kabachek, O. L. (Eds.) (2005). Bibliopsihologija i biblioterapija [Bibliopsychology and bibliotherapy]. Moskva: Shk. b-ka (rus).

11. Mishukova, E. O. (2011). Lechenie knigoj, ili Osnovy biblioterapii [Treatment of book, or the Basics of bibliotherapy]. Moskva: Prosveshhenie trudjashhihsja (rus).

12. Nova ukraisnska shkola [New Ukrainian school]. Retrieved from: https://mon.gov.ua/ storage/app/media/zagalna\%20serednya/nova-ukrainska-shkola-compressed.pdf (ukr).

13. Polakova, H. P. (2010). Napriamy modeliuvannia indyvidualnoi traiektorii bezperervnoi osvity y samoosvity pedahohichnykh pratsivnykiv [Directions of modeling of individual trajectory of continuous education and self-education of pedagogical workers]. Teoriia ta metodyka upravlinnia osvitoiu, 3, 11. Retrieved from http://umo.edu.ua/images/ content/nashi_vydanya/metod_upr_osvit/v_3/28.pdf(ukr).

14. Postanova Kabinetu Ministriv Ukrainy «Deiaki pytannia profesiinoho rozvytku pedahohichnykh pratsivnykiv» vid 29 lypnia 2020r., №672 [Resolution of the Cabinet of Ministers of Ukraine «Some issues of professional development of teachers» of July 29, 2020 № 672]. Retrieved from https://ips.ligazakon.net/document/view/kp200672?an=1\&ed=2020_07_29 (ukr). 
15. Profesiine vyhorannia [Professional burnout]. Retrieved from: https://thelib.info/ psihologiya/1928810-obshhaya-harakteristika-metoda/ (ukr).

16. Shuliar, V. I. \& Hladyshev, V. V. Pedahohichna shkola vydatnoho metodysta Nily YosypivnyVoloshynoi (2020). [Pedagogical school of the outstanding methodologist Nila Yosypivna Voloshina]. Pedagogy in modern conditions / Bartienieva I., Nozdrova O., - etc. International Science Group. - Boston : Primediae Launch, 329 r. DOI: 10.46299/ISG.2020. MONO.PED.III. URL: https://isg-konf.com. S. 95-99 (ukr).

17. Shuliar, V. I. (2019). Stratehii orhanizatsii osvitnoho protsesu: do realizatsii Kontseptsii «Nova ukrainska shkola» [Strategies for organizing the educational process: to wardsth eimplementation of the «New Ukrainian school» Concept]. Dyrektor shkoly, 7 (847), 93-104 (ukr).

18. Shuliar, V. I. Uchytel yak liudskyi resurs Novoi ukrainskoi shkoly [Teacher as a human resource of the New Ukrainian school]. Mykolaiv: MOIPPO (ukr). 